\title{
Decrease of psychomotor performance in subjects with latent 'asymptomatic' toxoplasmosis
}

\author{
J. HAVLÍ ČEK ${ }^{1}$, Z. GAS̆OVÁ², A. P. SMITHH ${ }^{3}$, K. ZVÁRA ${ }^{4}$ and J. FLEGR ${ }^{1 *}$ \\ ${ }^{1}$ Department of Parasitology, Faculty of Science, Charles University, Viničná 7, 12844 Prague, Czech Republic \\ ${ }^{2}$ Institute of Haematology and Blood Transfusion, U nemocnice 1, 12000 Prague, Czech Republic \\ ${ }^{3}$ Centre for Occupational and Health Psychology, School of Psychology, Cardiff University, UK \\ ${ }^{4}$ Department of Probability and Statistics, Faculty of Mathematics and Physics, Charles University, Sokolovská 83, \\ 186 00, Prague 8, Czech Republic
}

(Received 24 fuly 2000 ; revised 13 November 2000 ; accepted 15 November 2000)

\section{SUMMARY}

Toxoplasma gondii is known to induce specific behavioural changes in its intermediate hosts. This is usually considered to be an evolutionary adaptation aimed to increase the probability of transmission of the parasite into its definitive host, the cat, by predation. In rodents an increase of reaction time as well as many other specific behavioural patterns have been observed. Here we report the results of our double blind study showing the significantly longer reaction times of 60 subjects with latent toxoplasmosis in comparison with those of 56 controls. Moreover, the existence of a positive correlation between length of infection and mean reaction time suggested that slow and cumulative effects of latent toxoplasmosis rather than a one-step (and possibly transient) effect of acute toxoplasmosis disease are responsible for the decrease of psychomotor performance of infected subjects. To our knowledge, this is the first study confirming the existence of such parasite-induced changes in human behaviour that could be considered in evolutionary history of the human species as adaptive from the point of view of parasite transmission.

Key words: manipulation hypothesis, parasite, human, reaction times, Toxoplasma gondii, behaviour, evolution.

\section{INTRODUCTION}

Toxoplasma gondii is a heteroxenic coccidian parasite of felids with an unusually wide range of intermediate and paratenic hosts, including humans. After a short phase of acute toxoplasmosis the infection proceeds into its latent phase when cysts are formed and these survive for the rest of the host's life, mainly in neural and muscular tissues of infected subjects. In immunocompetent subjects the latent phase of infection is considered asymptomatic and harmless. The prevalence of latent toxoplasmosis is very high in most developed and developing countries in the world, usually ranging from 30 to $70 \%$ (Schassan \& Kaskara, 1971; Perea \& Borobio, 1974; Develoux et al., 1988; Frenkel \& Ruiz, 1980; Petithory et al., 1996).

T. gondii is a classical model for the study of the manipulation hypothesis. Specific behavioural effects of latent toxoplasmosis which can be interpreted as special adaptation of the parasite to increase the probability of its transmission from intermediate to definitive host by carnivorism have been demonstrated in numerous studies with laboratory mice and rats. Infected mice have impaired motor performance (Hutchison, Aitken \& Wells, $1980 b$; Hay

* Corresponding author: Department of Parasitology, Faculty of Science, Charles University, Viničná 7, Prague 128 44, Czech Republic. Tel: + 4202 21953289. Fax: + 4202 24919704. E-mail: flegr@cesnet.cz et al. 1983 a), deficit in learning capacity and memory (Witting, 1979), higher activity levels both in novel and familiar environments (Hutchison, Aitken \& Wells, $1980 a$; Hay, Hutchison \& Aitken, $1983 b$; Hay et al. 1984b; Hay, Aitken \& Arnott, 1985), lower ability to discriminate between familiar and novel surroundings (Hutchison et al. $1980 a$; Hay, Aitken \& Graham, 1984a), and longer reaction times (Hrdá et al. 2000). Infected rats have higher activity levels (Webster, 1994), lower neophobia (Webster, Brunton \& Macdonald, 1994), reduced learning capacity (Witting, 1979) and lowered level of avoidance of a cat odour (Berdoy, Webster \& Macdonald, 2000). In human hosts, only indirect evidence for the existence of behavioural changes, namely, the shifts in personality profiles in subjects with latent toxoplasmosis have been observed (Flegr et al. 1996; Flegr, Kodym \& Tolarová, 2000).

A specific change that could be highly adaptive from the point of view of the life-cycle of $T$. gondii would be an increase in the reaction time of infected intermediate hosts. Under natural conditions such changes can increase the probability that an infected intermediate host would be captured and eaten by a cat. In a modern human such changes would be nonproductive from the point of view of $T$. gondii transmission, however, they still could exist here. To search for this specific change in the behaviour of Toxoplasma-infected subjects we measured the psychomotor performance of men and women immuno- 
logically tested for latent toxoplasmosis. Here we report the results of a comparison of simple reaction times in a set of 116 subjects with and without latent toxoplasmosis.

MATERIALS AND METHODS

\section{Subjects}

The experimental set consisted of 69 men and 47 women, the donors of thrombocytes at the Institute of Haematology and Blood Transfusion, Prague. During the thrombocyte separation sessions the donors were asked to take part in a reaction time test. The tests were carried out in the morning (to avoid possible diurnal differences in performance), after the end of the thrombocyte separation session under standard laboratory conditions. The method of recruitment of subjects as well as the data handling was in accordance with all current rules in $\mathrm{Czech}$ legislation.

\section{Psychomotor test}

Psychomotor performance was investigated by a computer version of a simple reaction time test. This test is widely used in studies of behavioural effect of viral infections (Smith et al. 1989; Hall \& Smith, 1996). A white square $(1 \times 1 \mathrm{~cm})$ appeared in the centre of the black computer display at irregular intervals ranging from 1 to $8 \mathrm{sec}$. The subject had to respond to the square immediately after it appeared on the display by pressing a key on a special keyboard. A 1-min training exercise was followed by a 3-min test. The computer measured and recorded reaction times of each trial. After the experiment a mean reaction time for each minute of the test and total mean reaction time for the whole $3 \mathrm{~min}$ of the test were computed omitting all outliers i.e. values more than 2.5 s.D. away from the raw mean reaction time for the particular subject. At the time of reaction time testing neither the subjects nor the researcher were aware of the results of the immunological assessment of toxoplasmosis.

\section{Immunological tests for toxoplasmosis}

All serological tests were carried out in the National Reference Diagnostic Laboratory for Toxoplasmosis, the National Institute of Public Health, Prague. Specific IgG and IgM antibody titres for toxoplasmosis were determined by ELISA, optimized for early detection of acute toxoplasmosis (Pokorný et al. 1989) and with complement fixation tests (CFT) which are more sensitive and therefore more suitable for the detection of old T. gondii infections (Warren \& Sabin, 1942). The titre of anti-Toxoplasma antibodies in sera was measured in dilutions between $1: 8$ and $1: 1024$. The subjects with CFT titres between $1: 8$ and $1: 128$ were considered latenttoxoplasmosis positive. No subjects with titres equal or higher than 1:256 or with other indications of recent acute toxoplasmosis (e.g. high titres in $\mathrm{IgG}$ and IgM ELISA) were involved in the study.

\section{Statistics}

The Statistica ${ }^{\circledR}$ v. 5.0 program was used for all statistical testing including evaluating statistical test assumptions, namely the normality of data distribution, homogeneity of variances, and interaction by covariates (parallelism). The women had slightly longer reaction times than men in the $3 \mathrm{rd}$ min of the test (ANCOVA, $\mathrm{F}_{1,111}, P=0.038$ ). However, after the Bonferroni correction for multiple tests no statistically significant differences between men and women were observed either in reaction time, or in the prevalence of latent toxoplasmosis, and therefore both sexes were analysed together. Without a logarithmic transformation, the distributions of reaction times were slightly asymmetrical and also the distribution of residuals of ANOVA tests were significantly skewed (independent variables TOXO and SEX, Shapiro-Wilk normality test, $W=0.9691$, $P=0.009$ ). However, the results of all tests performed on transformed and non-transformed data were similar and therefore only the results for the non-transformed data are reported in the present study.

An analysis of covariance (ANCOVA) was used to study the effects of toxoplasmosis (independent variable TOXO), and age of subject (confounding variable $\mathrm{AGE}$ ), on reaction time in the $1 \mathrm{st}, 2 \mathrm{nd}$ and $3 \mathrm{rd} \mathrm{min}$ of the test (dependent variables). ANCOVA with repeated measures (reaction times in the 1 st, 2nd and $3 \mathrm{rd}$ min of the test) was used for estimation of the effect of toxoplasmosis in the whole 3 min test and both ANCOVA and ANOVA with repeated measures for the study of the possible interaction between toxoplasmosis and duration of test (by post hoc tests). Scheffé tests were used for the post hoc comparison of differences in reaction times in the 1st, 2nd and 3rd min for Toxoplasma-negative and positive subjects. The effect of the elimination of the effect of age was negligible in post hoc tests i.e. the results of these tests were identical for ANCOVA and ANOVA. For testing of correlation between the anti-Toxoplasma antibodies titres (five-points ordinal scale 1, 2, 3, 4, 5 for titres $1: 8,1: 16,1: 32,1: 64$ and $1: 128$, respectively) and the reaction time we used nonparametric Kendall tests. The effect of age was controlled by using residuals of regression between age (independent variable) and reaction time (dependent variable) instead of raw reaction times in our Kendall test.

\section{RESULTS}

The results of the simple reaction time test for 56 Toxoplasma-negative and 60 Toxoplasma-positive subjects are shown in the Fig. 1. The results of one- 


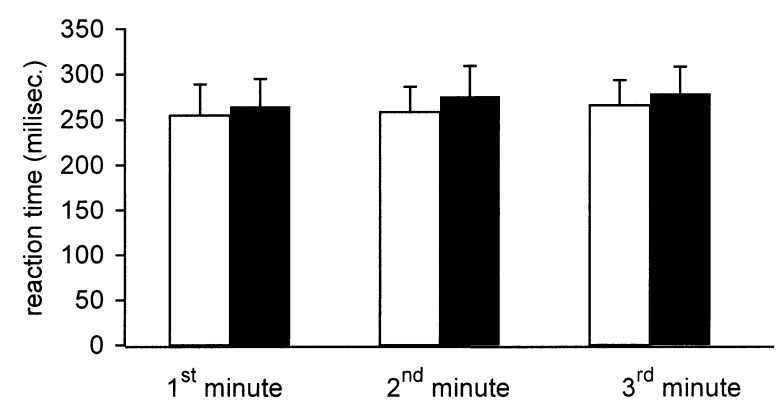

Fig. 1. Mean reaction time (in msec) in 1 st, 2nd and 3 rd min of the test. Error bars show standard deviation. Light columns, non-infected; dark columns, infected subjects.

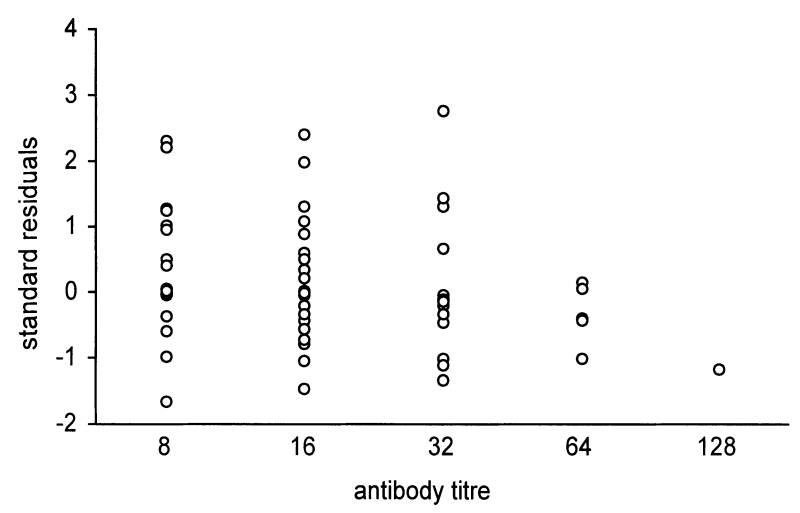

Fig. 2. Correlation between antibody titre and mean reaction time in the whole 3 -min interval of the test. The abscissa shows standard residuals of simple linear regression between the age and total mean reaction time, the ordinate shows the antibody titre measured with CFT.

sided ANCOVA tests (with elimination of a possible effect of age) showed that Toxoplasma-positive subjects had significantly longer reaction times in the second $\left(\mathrm{F}_{1,113}=7 \cdot 6, \quad P=0.0034, \mathrm{R}^{2}=0.084\right)$ and third $\left(\mathrm{F}_{1,113}=4.8, P=0.015, \mathrm{R}^{2}=0.076\right) \mathrm{min}$ as well as in the whole 3 min interval of the test (ANCOVA with repeated measures, $\mathrm{F}_{1,113}=5 \cdot 41$, $P=0 \cdot 011)$. In the 1 st min of the test the difference between Toxoplasma-positive and Toxoplasma-negative subjects was not significant $\left(\mathrm{F}_{1.113}=2 \cdot 0, P=\right.$ $0 \cdot 079, \mathrm{R}^{2}=0 \cdot 037$ ). Post hoc comparison (with twotailed Scheffé test) showed that a significant reduction of psychomotor performance occurred between the 1 st and $3 \mathrm{rdmin}(P=0.030)$ but not between the 1 st and 2nd min $(P=0.91)$ in the Toxoplasma-negative and between the 1 st and 2 nd $\min (P=0 \cdot 015)$ but not between the 2 nd and $3 \mathrm{rd}$ min $(P=0.95)$ in the Toxoplasma-positive subjects.

To reveal whether the difference in reaction times between Toxoplasma-negative and Toxoplasma-positive subjects increases or decreases with duration of the $T$. gondii infection, we measured the correlation between reaction times and the anti-Toxoplasma IgG antibodies titres. The moment of $T$. gondii infection is usually not known for most subjects with latent toxoplasmosis. Statistically, however, it can be indirectly estimated based on the level of $\operatorname{IgG}$ antibodies, which is usually very high during acute toxoplasmosis but which decreases within months or several years after the infection (Konishi, 1989). After removing the effect of age, a one-sided nonparametric correlation analysis of data from 60 Toxoplasma-positive subjects revealed the existence of a negative association between the level of antiToxoplasma antibodies and the mean reaction time in the 1st (Kendall tau $=-0.175, P=0 \cdot 019$ ), 2nd (Kendall tau $=-0.078, P=0.024)$ and 3rd (Kendall tau $=-0.193, P=0.038)$ min as well as in the whole 3 min interval (Kendall tau $=-0 \cdot 183, P=0 \cdot 014$ ) of the test (Fig. 2).

\section{DISCUSSION}

In a double blind study we demonstrated the deterioration of psychomotor performance (increase of reaction times) of subjects with latent toxoplasmosis. The differences between Toxoplasmapositive subjects and Toxoplasma-negative controls were rather low in the subjects with high level of anti-Toxoplasma antibodies and increased with decrease of the antibody level (i.e. with duration of $T$. gondii infection).

In the 1 st min of the test there is no significant difference in psychomotor performance between Toxoplasma-negative and Toxoplasma-positive subjects. The prominent reduction in psychomotor performance occurred between the 1 st and $3 \mathrm{rd}$ min of the test but not between the $1 \mathrm{st}$ and $2 \mathrm{nd} \min$ in the Toxoplasma-negative subjects and between the 1 st and $2 \mathrm{nd}$ min but not between the $2 \mathrm{nd}$ and $3 \mathrm{rd}$ min of the test in the Toxoplasma-positive subjects. This suggests that the Toxoplasma-positive subjects probably get tired more quickly than Toxoplasmanegative controls. It indicates that Toxoplasmapositive subjects have a deteriorated ability of longterm concentration rather than prolonged simple reaction time under the optimal conditions of maximum concentration of the $1 \mathrm{st}$ min of the test.

The difference between Toxoplasma-positive subjects and Toxoplasma-negative controls was only 10 , 17 and $13 \mathrm{msec}$ on the $1 \mathrm{st}$, 2nd and $3 \mathrm{rd}$ min of the test, respectively. In fact, even in the second min of the test the coefficient of determination $\mathrm{R}^{2}$ was $0 \cdot 084$, and therefore the effects of latent toxoplasmosis explained only about $8.4 \%$ of total variability of reaction times in our experimental set. However, it must be stressed that our experimental set of Toxoplasma-positive subjects contained many subjects with relatively recent infections (i.e. the subjects whose psychomotor performance was changed only slightly in comparison with uninfected controls). It is also highly probable that the subset of Toxoplasma- 
negative subjects was in fact contaminated with false negatives i.e. with subjects with very long infection (and very low level of anti-toxoplasma antibodies) (Flegr \& Havliček, 1999). Moreover, the length of infection is always positively correlated with the age of infected subjects. No statistical method exists that can eliminate the effect of age without at least partly removing also the effect of length of infection on the reaction times of experimental subjects. Therefore, our statistical tests probably downgraded the effects of latent toxoplasmosis on the psychomotor performance.

The increase of the differences between Toxoplasma-infected subjects and controls with the decrease of specific antibody levels (and therefore with the duration of infection) suggests that slow and cumulative effects of latent toxoplasmosis rather than a one-step and possibly transient effect of acute toxoplasmosis disease is responsible for the decrease of psychomotor performance of infected subjects. The physiological mechanism of the effect is not known. It is currently supposed that probably all infected people bear dormant stages of $T$. gondii i.e. bradyzoites in zoitocysts located mainly in the neural and muscular tissue, for the rest of their life (Remington \& Krahenbuhl, 1982). The parasite can resume its pathogenic activity and even kill its host only after severe deterioration of the immune system, for example in AIDS patients (Grant et al. 1990; Ortona et al. 1991; Zufferey et al. 1993; Halonen, Lyman \& Chiu, 1996; Arendt et al. 1999) or immunosuppressed transplantation patients (Figueiredo et al. 1983; Derouin et al. 1986; Gallino et al. 1996). Under normal conditions, latent toxoplasmosis is considered asymptomatic in human and even immunoprotecting pregnant women from acute toxoplasmosis (and their children from the danger of congenital toxoplasmosis). In mice, however, histopathological changes in cyst-containing regions of brain, including inflammatory granulomatous changes of perivascular areas, progressive deposition of necrotic material resulting finally in an occlusion and subsequent sclerosis of vessels, was observed (Werner, Masihi \& Senk, 1981). Even in relatively resistant strains of mice the latent toxoplasmosis was accompanied by permanently increased levels of mRNA of the cytokines TNF-alpha and IL-10 (Arsenijevic et al. 1997).

AIDS patients with neurotoxoplasmosis usually express multifocal lesions mostly in basal ganglia and thalami (Sparacia et al. 1998). Histopathological data for immununocompetent subjects are not available. However, indirect observations suggesting a possible influence of 'asymptomatic' latent toxoplasmosis on human health are available in the literature from the late seventies. It was shown that latent Toxoplasma infection can diminish learning capacity of children (Hengst, 1979). The studies performed on 5 independent large experimental sets showed that subjects with latent toxoplasmosis significantly differed in several personality factors from uninfected controls (Flegr \& Hrdý, 1994; Flegr et al. 1996; Flegr \& Havlíček, 1999). The personality changes increased with length of latent toxoplasmosis estimated on the basis of either antibody level (one experimental set) or date of acute phase of infections (two experimental sets) (Flegr et al. 1996, 2000), suggesting that the cumulative changes in personality profiles of infected subjects are induced by the parasite, rather than that a certain combination of personality factors influences an acquisition rate of $T$. gondii infection.

The behavioural changes associated with latent or chronic toxoplasmosis in humans and animals are usually studied and interpreted in the context of the manipulation hypothesis. Increase of reaction times and other changes observed in rodents can theoretically increase the chance of transmission of $T$. gondii into a definitive host, a cat. In modern human (but possibly not in his ancestors), this manipulation activity is unproductive for the parasite. However, the decrease of psychomotor performance or ability of long-term concentration of infected subjects can play an important role in many situations even in our modern world. Because of its extremely high prevalence $(30-70 \%$ in most countries), latent toxoplasmosis, the mildest form of $T$. gondii infection, might in fact represent a very serious and highly underestimated public health problem.

This research was supported by the grants GAUK107/1998 and J13/981131-B4.

\section{REFERENCES}

ARENDT, G., VON GIESEN, H. J., HEFTER, H., NEUEN-JACOB, E., ROICK, H. \& JABLONOWSKI, H. (1999). Long-term course and outcome in AIDS patients with cerebral toxoplasmosis. Acta Neurologica Scandinavica 100, $178-184$.

ARSENijeviC, D., Girardier, L., SEydoux, J., CHANG, H. R. \& DUlloo, A. G. (1997). Altered energy balance and cytokine gene expression in a murine model of chronic infection with Toxoplasma gondii. American Fournal of Physiology 272, E908-E917.

BERDoy, M., Webster, J. P. \& MACDONALD, D. W. (2000). Fatal attraction in rats infected with Toxoplasma gondii. Proceedings of the Royal Society of London, B 267, 591-594.

Derouin, F., Gluckman, E., Beauvais, B., Devergie, A., MELO, R., MONNY, M. \& LARIVIERE, M. (1986).

Toxoplasma infection after human allogeneic bone marrow transplantation: clinical and serological study of 80 patients. Bone Marrow Transplantation 1, 67-73. Develoux, M., CANDOlfi, E., HANGO-DOUnBo, s. \& KIEN, T. (1988). La toxoplasmose au Niger. Bulletin de la société de Pathologie Exotique 81, 253-259.

Figueiredo, J. F., MOYSES-NETO, M., GOMES, U. A., SUAID, H., Ferraz, A. S., Martins, A. C. \& Fiorillo, A. M. 
(1983). Antibody titers to Toxoplasma gondii in renal transplant patients. Brazilian Fournal of Medical and Biological Research 16, 235-239.

FLEGR, J. \& HAVLÍčEK, J. (1999). Changes in the personality profile of young women with latent toxoplasmosis. Folia Parasitologica (Praha) 46, 22-28.

FLEGR, J. \& HRDÝ, I. (1994). Influence of chronic toxoplasmosis on some human personality factors. Folia Parasitologica (Praha) 41, 122-126.

Flegr, J., Kodym, P. \& TOlarová, v. (2000). Correlation of duration of latent Toxoplasma gondii infection with personality changes in women. Biological Psychology 53, 57-68.

FLEGR, J., ZITKOVÁ, S., KODYM, P. \& FRYNTA, D. (1996). Induction of changes in human behaviour by the parasitic protozoan Toxoplasma gondii. Parasitology 113, 49-54.

FRENKEL, J. K. \& RUIZ, A. (1980). Human toxoplasmosis and cat contact in Costa Rica. American Fournal of Tropical Medicine and Hygiene 29, 1167-1180.

GALlino, A., MAGgiorini, M., KiOWSKi, W., MaRTin, x., WUNDERLI, W., SCHNEIDER, J., TURINA, M. \& FOLLATH, F. (1996). Toxoplasmosis in heart transplant recipients. European Fournal of Clinical Microbiology and Infectious Diseases 15, 389-393.

GRANT, I. H., GOLD, J. W., ROSENBLUM, M., NIEDZWIECKI, D. \& ARMSTRONG, D. (1990). Toxoplasma gondii serology in HIV-infected patients: the development of central nervous system toxoplasmosis in AIDS. AIDS 4, 519-521.

HALL, S. R. \& SMITH, A. P. (1996). Behavioural effects of infectious mononucleosis. Neuropsychobiology 33, 202-209.

Halonen, s. K., Lyman, W. D. \& CHIU, F. C. (1996). Growth and development of Toxoplasma gondii in human neurons and astrocytes. Fournal of Neuropathology and Experimental Neurology 55, 1150-1156.

HAY, J., Aitken, P. P. \& ARnotT, M. A. (1985). The influence of Toxoplasma infection on the spontaneous running activity of mice. Zeitschrift für Parasitenkunde 71, 459-462.

HAY, J., AITKEN, P. P. \& GRAHAM, D. I. $(1984 a)$. Toxoplasma infection and response to novelty in mice. Zeitschrift für Parasitenkunde 70, 575-588.

HAY, J., AITKEN, P. P., HAIR, D. M., HUTCHISON, W. M. \& GRAHAM, D. I. $(1984 b)$. The effect of congenital Toxoplasma infection on mouse activity and relative preference for exposed areas over a series of trials. Annals of Tropical Medicine and Parasitology 78, 611-618.

HAY, J., AITKEN, P. P., HUTChiSON, W. M. \& GRAHAM, D. I. $(1983 a)$. The effect of congenital and adult-acquired Toxoplasma infections on the motor performance of mice. Annals of Tropical Medicine and Parasitology 77, 261-277.

HAY, J., HUTChison, W. M. \& AitKen, P. P. (1983 b). Congenital Toxoplasma infection and response to novelty in mice. Annals of Tropical Medicine and Parasitology 77, 437-439.

HENGST, P. (1979). Zur Häufigkeit und Entwicklung der Kinder mit latenter konnataler Toxoplasma gondiiInfektion. Angewandte Parasitologie 20, 216-221.
HRDÁ, š., VOTÝPKA, J., KODYM, P. \& FLEGR, J. (2000). Transient nature of Toxoplasma gondii-induced behavioral changes in mice. Fournal of Parasitology 86, 657-663.

hutchison, W. M., Aitken, P. P. \& Wells, B. W. P. (1980 a). Chronic Toxoplasma infection and familiarity-novelty discrimination in the mouse. Annals of Tropical Medicine and Parasitology 74, 145-150.

HUTChison, W. M., Aitken, P. P. \& Wells, B. W. P. $(1980$ b). Chronic Toxoplasma infections and motor performance in the mouse. Annals of Tropical Medicine and Parasitology 74, 505-510.

KONISHI, E. (1989). Annual change in immunoglobulin G and $\mathrm{M}$ antibody levels to Toxoplasma gondii in human sera. Microbiology and Immunology 33, 403-411.

ortona, L., ANTINORI, A., TAMBURRINi, E., CAPELli, A., FAMILIARI, U., MARANO, P. \& COLOSIMO, C. (1991). AIDS and the central nervous system: correlations between clinical, radiological and anatomopathological aspects. A critical review of 40 personal cases. Annali Italiani di Medicina Interna $\mathbf{6}$, 193-202.

PEREA, E. J. \& BOROBio, M. v. (1974). Facteurs epidemiologiques et caracteres cliniques de la toxoplasmose en Espagne. Bulletin de la Société de Pathologie Exotique 67, 183-193.

Petithory, J. C., Ambroise thomas, P., Deloye, J., PEllouX, H., GOUllier FleUret, A., Milgram, M., BUfFARD, C., GARIN, J. P., BESSIERES, M. H., PARIShamelin, A., PESTRE AlEXANDre, M., BaUfineducrocQ, H., CAZENAVE, J., COUZineau, P., DERouin, F., DUPOUYCAMET, J., JACQUEMIN, J. L., KIEN, T., LeCOlier, B., NIEL, G., PINON, J. M., QUilici, M., ROBERT, R., SEgUela, J. P., SENET, J. M., ThUlliez, P., JACQUiER, P., JANITSCHKE, K. \& REITER, I. (1996). Serodiagnosis of toxoplasmosis: A comparative multicentre study of a series of control sera using various currently available tests and expression of the results in International Units. World Health Organization Bulletin 74, 291-298.

POKORNÝ, J., FRUHBAUER, Z., POLEDŇÁKOVÁ, S., SÝKORA, J., ZÁsTĚra, M. \& FIALOVÁ, D. (1989). Assessment of antitoxoplasmatic IgG antibodies with the ELISA method. Československá Epidemiologie 38, 355-361.

REMINGTON, J. S. \& KRAHENBUHL, J. L. (1982). Immunology of Toxoplasma gondii. In Immunology of Human Infection, Part II (ed. Nahmias, A. J. \& O’Reilly, J.), pp. 327-371. Plenum Publishing Corporation, New York.

SCHASSAN, H.-H. \& KASKaRA, s. (1971). Die Durchseuchung mit Toxoplasma gondii in Hamburg. Zeitschrift für Tropenmedizin und Parasitologie 22, 165-177.

SMith, A. P., TYRRELl, D. A. J., AL-NAKIB, W., BARROW, P. G., HIGGINS, P. G., LEEKAM, S. \& TRICKETT, S. (1989). Effects and after-effects of the common cold and influenza on human performance. Neuropsychobiology 21, 90-93.

SPARACIA, G., BRANCATElli, G., SARNO, C., DEMARIA, M., LAGAlla, R. \& FILOSTO, L. (1998). Value of magnetic resonance in the diagnostic definition of neurotoxoplasmosis and in the assessment of the 
response to pharmacological treatment. Radiology and Medicine 96, 23-28.

WARREN, J. \& SABIN, A. B. (1942). The complement fixation reaction in toxoplasmic infection. Proceedings of the Society for Experimental Biology and Medicine 51, 11-16.

Webster, J. P. (1994). The effect of Toxoplasma gondii and other parasites on activity levels in wild and hybrid Rattus norvegicus. Parasitology 109, 583-589. WEBSTER, J. P., BRUNTON, C. F. A. \& MACDONALD, D. W. (1994). Effect of Toxoplasma gondii upon neophobic behaviour in wild brown-rats, Rattus norvegicus.

Parasitology 109, 37-43.
WERNER, H., MASIHI, K. N. \& SENK, U. (1981). Latent Toxoplasma-infection as a possible risk factor for CNS-disorders. Zentralblatt für Bakteriologie, Mikrobiologie und Hygiene A 250, 368-375.

WitTING, P.-A. (1979). Learning capacity and memory of normal and Toxoplasma-infected laboratory rats and mice. Zeitschrift für Parasitenkunde 61, 29-51.

Zufferey, J., SUGAR, A., RUdAz, P., BILle, J., GLAUSER, M. P. \& Chave, J. P. (1993). Prevalence of latent toxoplasmosis and serological diagnosis of active infection in HIV-positive patients. European Fournal of Clinical Microbiology and Infectious Diseases 12, 591-595. 